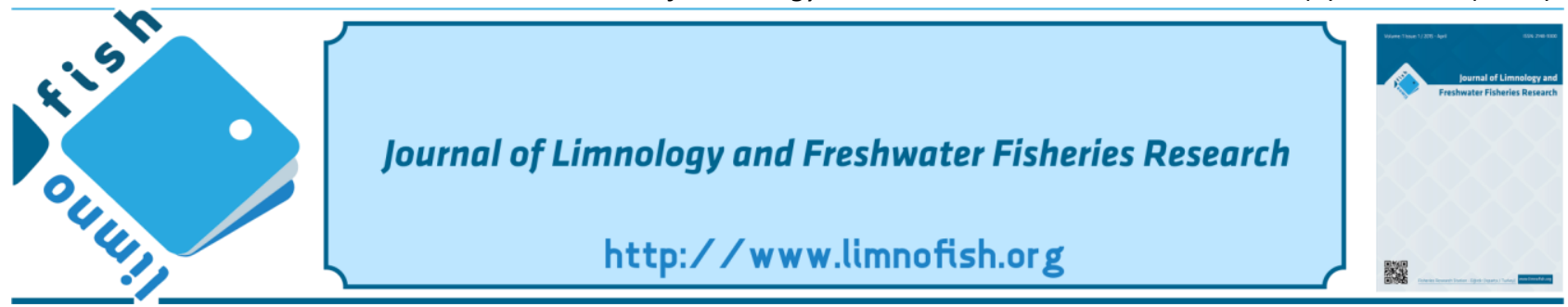

\title{
Assessment of Chromogenic Media in Bacterial Fish Pathogens
}

\author{
Tevfik Tansel TANRIKUL1 ${ }^{1}$, Ezgi DİÇTÜRK ${ }^{1 *}$ (D) \\ ${ }^{1}$ Izmir Katip Celebi University, Faculty of Fisheries, Department of Aquaculture, 32620 Çiğli-İzmir-Turkey
}

\section{A B S TRACT}

Accurate and quick identification of bacterial fish disease has great importance for effective disease control and prevent economic loss in aquaculture facilities. Generally used agar media allow the growth of wide-range bacteria but new chromogenic media results in colored colonies that lead to presumptive identification without requiring biochemical or serological tests. In this study, the recently commercialized chromogenic media; chromID ${ }^{\circledR} \mathrm{CPS}^{\circledR}$ Elite, chromID $^{\circledR}$ CPS $^{\circledR}$ Elite / Columbia CNA $+5 \%$ sheep blood agar, chromID ${ }^{\circledR}$ Vibrio, chromID ${ }^{\circledR}$ MRSA Smart and chromID ${ }^{\circledR}$ Staphylococcus aureus Elite (BioMérieux, France) were tested with growth performance and colony coloration of bacterial fish pathogens. chromID ${ }^{\circledR} \mathrm{CPS}^{\circledR}$ Elite and chromID ${ }^{\circledR} \mathrm{CPS}^{\circledR}$ Elite / Columbia CNA $+5 \%$ sheep blood agar were detected the most suitable culture media to grow for all five isolated fish pathogens (i.e., Aeromonas hydrophila, Lactococcus garvieae, Pseudomonas fluorescens, Yersinia ruckeri and Vibrio anguillarum). Of which, L. garvieae was the only one observed with green colonies. chromID ${ }^{\circledR}$ Vibrio designed for $V$. parahaemolyticus and V cholerae was lead dark pink/purple colonies by $V$. anguillarum. The chromID ${ }^{\circledR}$ MRSA Smart and chromID $^{\circledR} S$. aureus Elite were detected not effective for incubation of bacterial fish pathogens.

\section{ARTICLE INFO}

\section{RESEARCH ARTICLE}

Received : : 13.10 .2020

Revised : :23.12.2020

Accepted : :27.12.2020

Published : 26.08.2021

DOI:10.17216/LimnoFish.810225

\section{* CORRESPONDING AUTHOR}

ezgi.dincturk@ikc.edu.tr

Phone : +90 2323293535

Fax: +902323860888

Keywords: Chromogenic media, fish diseases, fish pathogens, isolation

\begin{abstract}
Bakteriyel Balık Patojenleri için Kromojenik Besiyerlerinin Değerlendirilmesi
Öz: Akuakültür işletmelerinde etkin hastalık kontrolü ve ekonomik kayıpların önlenmesi için bakteriyel balık hastalıklarının doğru ve hızlı tanımlanması büyük önem taşımaktadır. Genel olarak kullanılan agar besiyerlerinde çok çeşitli bakteri türünün üremesi gözlenirken, yeni kromojenik besiyerleri, biyokimyasal ve serolojik test gerektirmeden renkli koloni görünümüyle tahmini ön tanımlama imkânı sunmaktadır. Bu çalışmada yakın zamanda ticarileşen kromojenik besiyerlerinde (chromID ${ }^{\circledR}$ CPS $^{\circledR}$ Elite, chromID ${ }^{\circledR}$ CPS $^{\circledR}$ Elite / Columbia CNA $+5 \%$ sheep blood agar, chromID ${ }^{\circledR}$ Vibrio, chromID ${ }^{\circledR}$ MRSA Smart ve chromID $^{\circledR}$ Staphylococcus aureus Elite (BioMérieux, France)) bakteriyel balık patojenlerinin üremesi ve koloni renklenmeleri tespit edilmiştir. ChromID ${ }^{\circledR}$ CPS $^{\circledR}$ Elite ve chromID ${ }^{\circledR}$ CPS $^{\circledR}$ Elite / Columbia CNA $+5 \%$ sheep blood agarın test edilen 5 farklı bakteriyel balık patojeni (Aeromonas hydrophila, Lactococcus garvieae, Pseudomonas fluorescens, Yersinia ruckeri ve Vibrio anguillarum) için en uygun besiyeri olduğu, ancak sadece L. garvieae'nin yeşil koloni görünümü ile ürediği belirlenmiştir. Vibrio parahaemolyticus ve Vibrio cholerae'nın hızlı teşhisi için geliştirilen chromID ${ }^{\circledR}$ Vibrio besiyerinde V. anguillarum kolonileri koyu pembe/mor renkli olarak gözlenmiş, chromID ${ }^{\circledR}$ MRSA Smart ve chromID ${ }^{\circledR} S$. aureus Elite besiyerlerinin bakteriyel balık patojenlerinin üremesi için uygun olmadığ belirlenmiştir
\end{abstract}

Anahtar kelimeler: Kromojenik besiyeri, balık hastalıkları, balık patojenleri, izolasyon

How to Cite

Tanrikul TT, Dinçtürk E. 2021. Assessment of Chromogenic Media in Bacterial Fish Pathogens. LimnoFish. 7(2): 150-156. doi: 10.17216/LimnoFish.810225

\section{Introduction}

Along with the fastest growing food industry, aquaculture, and the increasing production rates, it is important to identify the fish diseases accurately and quickly that these diseases can cause great economic loss during the production cycle. Proper and quick identification is the most important step for diagnosis of the fish diseases.

The use of chromogenic media engenders the inhibition of nontarget organisms with differential and selective culture characteristics and target pathogens grow as colored colonies. The system of 
these chromogenic media depends on the metabolism of pathogens or enzyme substrates (Perry 2017). chromID ${ }^{\circledR}$ CPS $^{\circledR}$ Elite and chromID $^{\circledR}$ CPS $^{\circledR}$ Elite / Columbia CNA $+5 \%$ sheep blood are designed for isolation of urine specimens, Escherichia coli, Proteeae and Enterococcus; chromID ${ }^{\circledR}$ Vibrio is for presumptive identification of Vibrio parahaemolyticus and Vibrio cholerae; chromID ${ }^{\circledR}$ MRSA Smart and chromID ${ }^{\circledR}$ Staphylococcus aureus Elite for the direct screening of methicillin-resistant $S$. aureus (MRSA) and $S$. aureus in clinical microbiology. It is important to utilize these media for quick presumptive identification of the bacterial fish disease by easier prediagnosis in order to prevent economic loss in aquaculture facilities.

There is no single media for isolation of bacterial fish pathogens. Besides the generally used culture media, some selective media are used for eliminating the growth of a wide range of bacteria. Thiosulfate Citrate Bile Sucrose (TCBS) Agar was originally designed for the isolation of $V$. parahaemolyticus and $V$. cholerae but it is also used for the isolation of some Vibrio species that are infectious for fish such as $V$. alginolyticus, $V$. anguillarum, $V$. fischeri, $V$. harveyi, V. ordalii, V. splendidus and V. pelagus. Waltman-Shotts medium has been devised in order to isolate another fish pathogen, Yersinia ruckeri with precipitation of insoluble calcium salts around the colonies depending on the Tween 80 hydrolysis (Austin and Austin 2007). Similarly, Yersinia CIN agar supplies selective cultivation of Yersinia species, commonly for $Y$. pseudotuberculosis and $Y$. enterocolitica, but also for isolation of infectious fish pathogen, $Y$. ruckeri. GSP agar is a selective agar base for detection of Pseudomonas and Aeromonas and has been using for isolation of infectious Aeromonas and Pseudomonas species in fish. The Pseudomonas selective agar base, Cetrimide agar has been especially used for the isolation of Pseudomonas aeruginosa by yellow/green colonial growth. Likewise, Eosin Methylene-Blue (EMB) agar is selective for Enterobacteriaceae family, coliform bacteria and especially for $E$. coli by greenish metallic sheen colored colonies caused by the lactose fermentation.

The aim of this study was to test the growth and the selectivity of five commercially available chromogenic media (chromID ${ }^{\circledR}$ CPS $^{\circledR}$ Elite / Columbia CNA $+5 \%$ sheep blood, chromID $^{\circledR}$ CPS $^{\circledR}$ Elite, chromID ${ }^{\circledR} S$. aureus Elite, chromID ${ }^{\circledR}$ Vibrio, and chromID ${ }^{\circledR}$ MRSA Smart) for the isolation and presumptive identification of A. hydrophila, L. garvieae, P. fluorescens, $V$. anguillarum and $Y$. ruckeri while comparing its specificity and sensitivity with generally used selective media.

\section{Materials and Methods Medium}

The recently commercialized chromID $^{\circledR}$ CPS $^{\circledR}$ Elite / Columbia CNA $+5 \%$ sheep blood (product no. 418229), $\operatorname{chromID}^{\circledR} \mathrm{CPS}^{\circledR}$ Elite (product no. 418284), chromID ${ }^{\circledR}$ S. aureus Elite (product no. 419042), chromID $^{\circledR}$ Vibrio (product no. 43761) and chromID ${ }^{\circledR}$ MRSA Smart (product no. 413050) were purchased from BioMérieux (France) and compared with routinely employed selective agar media (Thiosulfate Citrate Bile Sucrose (TCBS-Merck, Germany) Agar, Cetrimide Agar (Merck, Germany), Yersinia CIN Agar (Merck, Germany), EMB Agar (Merck, Germany), Glutamate Starch Phenol Red Agar Pseudomonas Aeromonas Selective Agar (GSP, Merck, Germany) and Waltman-Shotts Medium for the isolation of Y. ruckeri (WS)) for detection and identification of infectious fish pathogens. In addition, comparison of the growth performance and advantages in isolation and identification were performed between new chromID ${ }^{\circledR}$ media and former media.

\section{Microbial Strains}

The bacterial fish pathogens previouslyisolated and identified from rainbow trout farms were used for all media. A. hydrophila, L. garvieae, P. fluorescens, $V$. anguillarum and $Y$. ruckeri were obtained from İzmir Katip Çelebi University, Faculty of Fisheries Fish Disease and Biotechnology Laboratory.

\section{Inoculation of Isolates onto Culture Media}

Each isolate was suspended in $1 \mathrm{ml}$ of saline $(0.85 \%)$ until the turbidity reached at $0.5 \mathrm{McFarland}$ standard (approximately $1.5 \times 10^{8} \mathrm{cfu} / \mathrm{ml}$ ) then they were inoculated onto each medium type by using a loop. The petri dishes were incubated at $21^{\circ} \mathrm{C}$. The growth was observed every 12, 24 and 48 hours of incubation. All strains were inoculated in duplicate on separate occasions.

\section{Results}

The growth of A. hydrophila on chromID $^{\circledR}$ CPS $^{\circledR}$ Elite was observed as pale brown colonies but no colonies grew on Columbia CNA $+5 \%$ sheep blood agar, chromID ${ }^{\circledR}$ MRSA Smart, chromID ${ }^{\circledR} S$. aureus Elite and chromID ${ }^{\circledR}$ Vibrio (Figure 1, Table 1). Yellowish/green colonies were observed on GSP agar which is selective for Pseudomonas/Aeromonas species. L. garvieae grew as green colonies on chromID ${ }^{\circledR} \mathrm{CPS}^{\circledR}$ Elite / 
Columbia CNA $+5 \%$ sheep blood and chromID ${ }^{\circledR}$ MRSA Smart, chromID ${ }^{\circledR}$ S. aureus Elite chromID ${ }^{\circledR}$ CPS $^{\circledR}$ Elite but was not recovered from and chromID ${ }^{\circledR}$ Vibrio (Figure 1, Table 1).

Table 1. Growth of different infectious fish pathogens on various media after $48 \mathrm{~h}$ of incubation at $21{ }^{\circ} \mathrm{C}$

\begin{tabular}{lcccccc}
\hline Species & $\begin{array}{c}\text { Total } \\
\text { number } \\
\text { of } \\
\text { isolates }\end{array}$ & $\begin{array}{c}\text { Growth on } \\
\text { chromID }{ }^{\circledR} \mathrm{CPS}^{\circledR} \\
\text { Elite } / \text { Columbia } \\
\text { CNA +5\% sheep } \\
\text { blood }\end{array}$ & $\begin{array}{c}\text { Growth on } \\
\text { chromID } \\
\text { Elite }\end{array}$ & $\begin{array}{c}\text { Growth on } \\
\text { chromID }^{\circledR} \\
\text { Vibrio }\end{array}$ & $\begin{array}{c}\text { Growth on } \\
\text { chromID }{ }^{\circledR} \text { MRSA } \\
\text { Smart }\end{array}$ & $\begin{array}{c}\text { Growth on } \\
\text { chromID }^{\circledR} \\
\text { S. aureus } \\
\text { Elite }\end{array}$ \\
\hline A. hydrophila & 2 & 2 & 2 & 0 & 0 & 0 \\
\hline L. garvieae & 21 & 21 & 21 & 0 & 0 & 0 \\
\hline P. fluorescens & 2 & 2 & 2 & 2 & 0 & 0 \\
\hline V. anguillarum & 6 & 6 & 6 & 6 & 0 & 0 \\
\hline Y. ruckeri & 14 & 14 & 14 & 3 & 2 & 3 \\
\hline
\end{tabular}

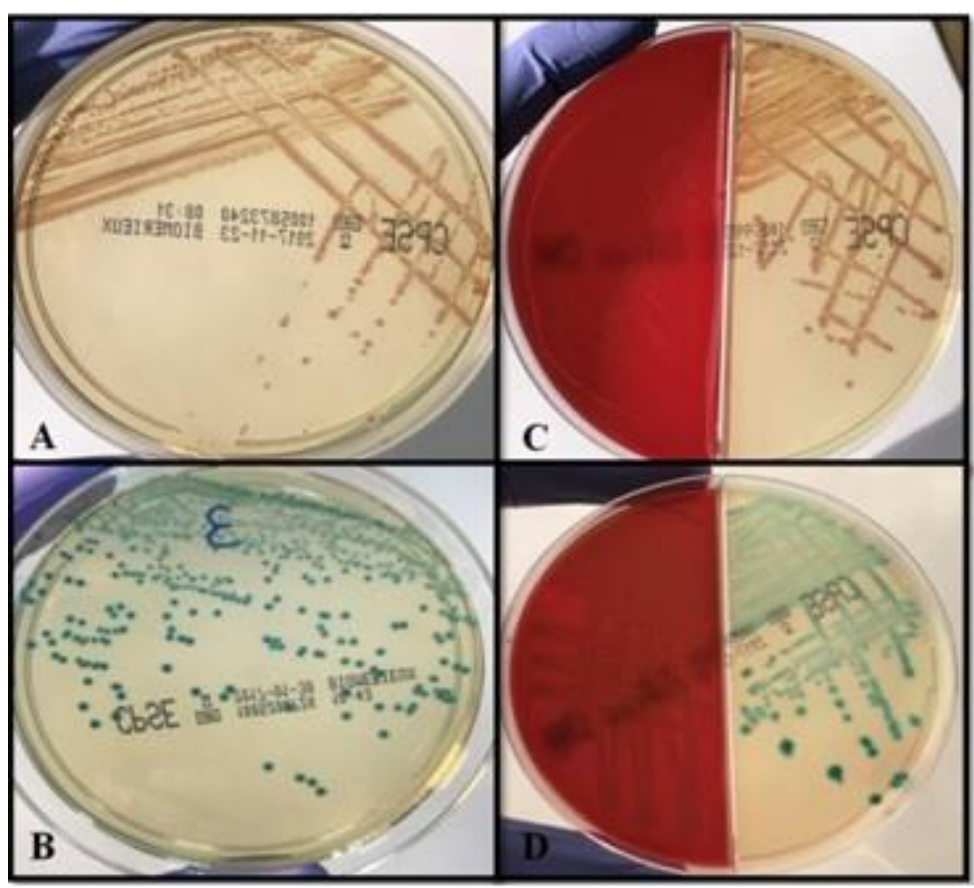

Figure 1. A: A. hydrophila on chromID ${ }^{\circledR} \mathrm{CPS}^{\circledR}$ Elite; B: L. garvieae on chromID ${ }^{\circledR} \mathrm{CPS}^{\circledR}$ Elite; C: A. hydrophila on chromID ${ }^{\circledR}$ CPS $^{\circledR}$ Elite / Columbia CNA $+5 \%$ sheep blood agar; D: L. garvieae on chromID ${ }^{\circledR}$ CPS $^{\circledR}$ Elite / Columbia CNA $+5 \%$ sheep blood agar

The colonial growth of $P$. fluorescens appeared on chromID ${ }^{\circledR}$ CPS $^{\circledR}$ Elite / Columbia CNA $+5 \%$ sheep blood and chromID ${ }^{\circledR}$ CPS $^{\circledR}$ Elite, moreover on chromID ${ }^{\circledR}$ Vibrio as orange colonies (Figure 2, Table 1). No colonies were presented on chromID ${ }^{\circledR}$ MRSA Smart and chromID ${ }^{\circledR} S$. aureus Elite. In addition, colonies were present on selective GSP and Cetrimide agar.

Vibrio anguillarum colonies were observed on chromID ${ }^{\circledR}$ CPS $^{\circledR}$ Elite as pale brown colonies and on chromID ${ }^{\circledR}$ Vibrio as dark pink/purple colonies but there was no colonial growth on Columbia CNA $+5 \%$ sheep blood agar, chromID ${ }^{\circledR}$ MRSA Smart and chromID ${ }^{\circledR} S$. aureus Elite (Figure 2, Table 1). In addition, yellow colored colonies appeared on TCBS agar which is the selective agar for Vibrio species.

Pale brown colonies of $Y$. ruckeri were present on chromID ${ }^{\circledR}$ CPS $^{\circledR}$ Elite but there was only weak growth on chromID ${ }^{\circledR}$ MRSA Smart and chromID ${ }^{\circledR} S$. aureus Elite with pink pigmentation and on chromID $^{\circledR}$ Vibrio with green pigmentation. There were no colonies detected on Columbia CNA $+5 \%$ sheep blood agar (Figure 3, Table 1). The precipitation of insoluble calcium salts around colonies were observed on Waltman-Shotts Medium and dark pink/red colonies were detected on Yersinia CIN Agar. 




Figure 2. A: P. fluorescens on chromID ${ }^{\circledR} \mathrm{CPS}^{\circledR}$ Elite; B: V. anguillarum on chromID ${ }^{\circledR} \mathrm{CPS}^{\circledR}$ Elite; C: P. fluorescens on chromID ${ }^{\circledR}$ CPS $^{\circledR}$ Elite / Columbia CNA $+5 \%$ sheep blood agar; D: V. anguillarum on chromID ${ }^{\circledR}$ CPS $^{\circledR}$ Elite / Columbia CNA $+5 \%$ sheep blood agar; E: P. fluorescens on chromID ${ }^{\circledR}$ Vibrio; F: V. anguillarum on chromID ${ }^{\circledR}$ Vibrio



Figure 3. A: Y. ruckeri on chromID ${ }^{\circledR} \mathrm{CPS}^{\circledR}$ Elite; B: Y. ruckeri on chromID ${ }^{\circledR}$ Vibrio; C: Y. ruckeri on chromID ${ }^{\circledR}$ CPS $^{\circledR}$ Elite / Columbia CNA $+5 \%$ sheep blood agar; D: Y. ruckeri on chromID ${ }^{\circledR}$ S. aureus Elite 


\section{Discussion}

The bacterial fish pathogens were plated on 5 different commercialized media and compared to selective media in order to detect colony morphologies, growth performance and efficiency for detecting and identifying infectious fish pathogens.

Based on the colony characteristics, chromID ${ }^{\circledR}$ CPS $^{\circledR}$ Elite agar has been recently commercialized and used for isolation and identification of urinary tract infections, especially E. coli in clinical microbiology. In addition, it is possible to detect Enterococcus spp., some members of Proteeae group and some members of Enterobacteriaceae, culture them and amplify antibiotic susceptibility tests. This media allows a preliminary identification for various microorganisms with genus or group level on the strength of colony appearance and Gram stain. Also, it is able to directly identify E. coli by the colony appearance without any requirement of Gram stain or biochemical testing (Yarbrough et al. 2016). The bacterial load of fish is less then urinary samples, it is likely that the selectivity of fish pathogens would be higher. In this study, all 5 bacterial fish pathogen grew on chromID ${ }^{\circledR} \mathrm{CPS}^{\circledR}$ Elite, especially green colony was observed with $L$. garvieae which is one of Gram-positive bacteria but $Y$. ruckeri which belongs to the family Enterobacteriaceae showed no distinctive colony coloration. Moreover, we have tested chromID ${ }^{\circledR} \mathrm{CPS}^{\circledR}$ Elite / Columbia CNA $+5 \%$ sheep blood which contains two different media on the same agar plate in half. Columbia CNA $+5 \%$ sheep blood agar is specific for the isolation and differentiation of Gram-positive microorganisms. Our results clearly showed that the chromID ${ }^{\circledR} \mathrm{CPS}^{\circledR}$ Elite / Columbia CNA $+5 \%$ sheep blood agar was highly selective to L. garvieae. Also, observing growth on both media on the same plate can lead to reliably compare the colony morphologies and coloration easily.

The members of the genus Vibrio have great importance because of the association with human disease as $V$. cholerae (the etiological agent of epidemic cholera) and $V$. parahaemolyticus (the cause of gastroenteritis associated with the consumption of seafood) (Farmer et al. 1985; Grimes 1991; Blanco-Abad et al. 2009; Eddabra et al. 2011). chromID ${ }^{\circledR}$ Vibrio was developed for determining $V$. cholerae and $V$. parahaemolyticus from other Vibrio species by the blue/green colonies of $V$. cholerae and pink colonies of $V$. parahaemolyticus on the medium. The TCBS Vibrio selective media was developed for isolation of pathogenic Vibrio species but it has poor sensitivity in natural specimens, labor-intensive and time-consuming. In addition, TCBS may not differentiate $V$. cholerae from $V$. alginolyticus or $V$. parahaemolyticus and $V$. fluvialis from $V$. mimicus or $V$. vulnificus (Eddabra et al. 2011). There is a slight selective advantage of chromID $^{\circledR}$ Vibrio because of the color colonies. It has indicated that its sensitivity is equivalent to TCBS medium and two times more specific as well as no confirmation is needed (Eddabra et al. 2011). Vibrio cholerae appears as blue-green colonies because of beta galactosidase-produce and $V$. parahaemolyticus grows pink colonies based on arabinose assimilation on chromID ${ }^{\circledR}$ Vibrio media. Pinto et al. (2011) reported that Vibrio CHROMagar plates (CAV, PBI International, Milan, Italy) displayed higher specificity and accuracy than TCBS agar for isolating $V$. parahaemolyticus and $V$. fluvialis. Furthermore, unlike TCBS medium, the CAV medium was more efficient to isolate $V$. parahaemolyticus for DNAbased typing analysis. The fish pathogen $V$. anguillarum was tested on chromID ${ }^{\circledR}$ Vibrio media for the first time in this study and observed dark pink/purple colonies. The color characteristic of $V$. anguillarum was not clear; therefore, further studies are needed to certify the reason of dark pink/purple coloration.

The direct screening of methicillin-resistant $S$. aureus (MRSA) is practicable with using chromID $^{\circledR}$ MRSA Smart in clinical microbiology. ChromID $^{\circledR} S$. aureus Elite is another media for the direct identification of $S$. aureus by spontaneous green coloration of glucosidase-producing colonies. Staphylococcus genus has been implicated as pathogen for fish and causing septicemia-like signs, exophthalmia and lesions around fins (Shotts and Teska 1989; Gil et al. 2000). Another important fish pathogen $L$. garvieae affects mainly rainbow trout farms that cause losses approximately $50 \%$ of the total production (Ghittino and Prearo 1992; Alrabadi 2012; Tanrikul 2012; Balta and Dengiz Balta 2019). Also, infected or carrier fish may spread the disease to healthy rainbow trout and lead to serious economic damage (Algöet et al. 2009). Several antibiotic treatments were applying such as enrofloxacin, florfenicol and oxytetracycline in order to control the outbreaks in Turkey (Kayış et al. 2009; Ture and Boran 2015). The antimicrobial resistant bacteria and its potential transfer between animals and human are the main concern and the antibiotic treatment may be not efficient in fish farms (Cabello et al. 2013; Muziasari et al. 2014; Ture and Boran 2015). In this study, we aimed to use both media for isolation of Staphylococcus while inhibiting the growth of $L$. garvieae but none of the fish pathogens were able to 
grow on chromID ${ }^{\circledR}$ MRSA Smart and chromID $^{\circledR} \quad S$. aureus Elite. These results clearly show that both of these media are not suitable for isolation and identification of fish pathogens.

The use of chromogenic media brings some advantages such as easy detection of target pathogens and differentiation of mixed cultures. On the contrary, these products are more expensive than conventional media but the disadvantage may be compensated by the reduction of complementary reagents and different culture plates for suspected pathogens (Perry and Freydiére 2007). Yarbrough et al. (2016) reported that using chromID ${ }^{\circledR}$ agar decrease the laboratory costs with reducing standard media consumption such as inoculation on both blood agar and MacConkey agar plates and additional biochemical tests.

In conclusion, the bacterial fish pathogens grew well in chromID ${ }^{\circledR} \mathrm{CPS}^{\circledR}$ Elite agar and chromID ${ }^{\circledR}$ CPS $^{\circledR}$ Elite / Columbia CNA $+5 \%$ sheep blood agar, $V$. anguillarum, P. fluorescens and $Y$. ruckeri grew well in chromID ${ }^{\circledR}$ Vibrio but pigment production was only observed for $V$. anguillarum. ChromID ${ }^{\circledR}$ CPS $^{\circledR}$ Elite agar, chromID ${ }^{\circledR}$ CPS $^{\circledR}$ Elite / Columbia CNA $+5 \%$ sheep blood agar and chromID $^{\circledR}$ Vibrio may be a practicable alternative to routinely employed chromogenic medium may be a feasible alternative to routinely used media. They are cost saving with reducing the number of agar plates and provide presumptive data by coloration specificity. Also in some cases, it is unnecessary to do confirmation tests such as Gram stain, oxidase test and determination of biochemical properties for presumptive identification.

\section{Acknowledgements}

The funding of the research Project 2017-GAPSUÜF-0005 was supported by İzmir Katip Çelebi University Scientific Research Projects Coordinatorship and this study was presented as "Use of New Bacteriological Mediums in the Isolation of Bacterial Fish Pathogens" in International Congress on Engineering and Life Science, 26-29 April 2018, Kastamonu-Turkey by oral presentation.

\section{References}

Algöet M, Bayley AE, Roberts EG, Feist SW, Wheeler RW, Verner- Jeffreys DW. 2009. Susceptibility of selected freshwater fish species to a UK Lactococcus garvieae isolate. J Fish Dis. 32(10):825-834. doi: 10.1111/j.1365-2761.2009.01058.x

Alrabadi NI. 2012. The effect of several antibiotics on Lactococcus garvieae isolated from Jordanian dairy products. Am J Agric Biol Sci. 7(4):468-472. doi: 10.3844/ajabssp.2012.468.472
Austin B, Austin DA. 2007. Bacterial Fish Pathogens 4th ed. the UK: Springer $552 \mathrm{p}$.

Balta F, Dengiz Balta Z. 2019. The Isolation of Lactococcus garvieae from Eyes of Diseased Rainbow Trout (Oncorhynchus mykiss) with Exopthalmia. J Anatolian Env and Anim Sciences. 4(1):27-33. doi: $10.35229 /$ jaes. 527258

Blanco-Abad V, Ansede-Bermejo J, Rodriguez-Castro A, Martinez-Urtaza J. 2009. Evaluation of different procedures for the optimized detection of Vibrio parahaemolyticus in mussels and environmental samples. Int $\mathbf{J}$ Food Microbiol. 129(3):229-236.

doi: 10.1016/j.ijfoodmicro.2008.11.028

Cabello FC, Godfrey HP, Tomova A, Ivanova L, Dölz H, Millanao A, Buschmann AH. 2013. Antimicrobial use in aquaculture re-examined: its relevance to antimicrobial resistance and to animal and human health. Environ Microbiol. 15(7):1917-1942. doi: 10.1111/1462-2920.12134

Eddabra R, Piemont Y, Scheftel JM. 2011. Evaluation of a new chromogenic medium, chromID ${ }^{\mathrm{TM}}$ Vibrio, for the isolation and presumptive identification of Vibrio cholerae and Vibrio parahaemolyticus from human clinical specimens. Eur J Clin Microbiol. 30(6):733-737.

doi: $10.1007 / \mathrm{s} 10096-010-1145-2$

Farmer JJ, Hickman-Brenner FW, Kelly MT. 1985. Vibrio. In: Lennette EH, Balows A, Hausler Jr WJ, Shadomy HJ, editors. Manual of Clinical Microbiology, 4th ed. Washington DC: American Society for Microbiology Press. p. 282-301.

Ghittino C, Prearo M. 1992. Report of Streptococcosis in rainbow trout (Oncorhynchus mykiss) in Italy: preliminary note. Boll Soc Ital Patol. 8:4-9.

Gil P, Vivas J, Gallardo CS, Rodriguez LA. 2000. First isolation of Staphylococcus warneri, from diseased rainbow trout, Oncorhynchus mykiss (Walbaum), in Northwest Spain. J Fish Dis. 23(4):295-298. doi: $10.1046 /$ j.1365-2761.2000.00244.x

Grimes DJ. 1991. Ecology of estuarine bacteria capable of causing human disease: a review. Estuaries. 14(4):345-360. doi: $10.2307 / 1352260$

Kayış S, Çapkın E, Balta F, Altınok I. 2009. Bacteria in rainbow trout (Oncorhynchus mykiss) in the Southern Black Sea Region of Turkey - A survey. Isr J Aquacult-Bamid.61(4):339-344. doi: $10.46989 / 001$ c. 20564

Muziasari WI, Managaki S, Pärnänen K, Karkman A, Lyra C, Tamminen M, Suzuki S, Virta M. 2014. Sulphonamide and trimethoprim resistance genes persist in sediments at Baltic Sea aquaculture farms but are not detected in the surrounding environment. PlosOne.9(3):e92702. doi:10.1371/journal.pone.0092702

Perry JD, Freydière AM. 2007. The application of chromogenic media in clinical microbiology. J Appl 
Microbiol. 103(6):2046-2055.

doi: 10.1111/j.1365-2672.2007.03442.x

Perry JD. 2017. A decade of development of chromogenic culture media for clinical microbiology in an era of molecular diagnostics. Clin Microbiol Rev. 30(2):449-479.

doi: 10.1128/CMR.00097-16

Pinto A, Terio V, Novello L, Tantillo G. 2011. Comparison between thiosulphate-citrate-bile salt sucrose (TCBS) agar and CHROMagar Vibrio for isolating Vibrio parahaemolyticus. Food Control. 22(1):124-127.

doi: 10.1016/j.foodcont.2010.06.013

Shotts EB, Teska JD. 1989. Bacterial pathogens of aquatic vertebrates. In: Austin B, Austin DA, editors. Methods for the Microbiological Examinationof Fish and Shellfish. Oxford: Ellis Horwood Ltd. p. 164-181.
Tanrikul TT. 2012. Efficacy of a whole cell Lactococcus garvieae vaccine in rainbow trout (Oncorhynchus mykiss). J Anim Vet Adv. 11(7):886-889. doi: 10.3923/javaa.2012.886.889

Ture M, Boran H. 2015. Phenotypic and genotypic antimicrobial resistance of Lactococcus sp. strains isolated from rainbow trout (Oncorhynchus mykiss). Bull Vet Inst Pulawy. 59(1):37-42. doi: 10.1515/bvip-2015-0006

Yarbrough ML, Wallace MA, Marshall C, Mathias E, Burnham CAD. 2016. Culture of urine specimens using chromID CPS elite medium can expedite Escherichia coli identification and reduce hands-on time in the clinical laboratory. J Clin Microbiol. 54(11):2767-2773. doi: 10.1128/JCM.01376-16 